\title{
Penanggulangan Banjir/Genangan Dan Konservasi Air Tanah Dengan Pembuatan Sumur Resapan Di SMP Negeri 8 Menteng Jakarta Pusat
}

\author{
Desi Putri ${ }^{1}$; Endah Lestari ${ }^{2}$; Rr Mekar Ageng Kinasti ${ }^{3}$; \\ Ranti Hidayawanti ${ }^{4}$; Iriansyah BM Sangadji ${ }^{5}$ \\ 1, 2, 3, 4,5 Institut Teknologi PLN \\ ${ }^{1}$ desi.putri@itpln.ac.id
}

\begin{abstract}
Jakarta is one of area that often experiences in flooding. Jakarta is increasingly vulnerable being affected due to the limited catchment area. Massive development with water tight surface conditions and limited water absorption caused by about $85 \%$ of rainfall falls in the Jakarta area. As a result of lack absorption in Jakarta, the amount of rain falling and flowing into the sea and rivers will increase. When the capacity of the river does not cover the river water automatically overflows it will cause flooding. Mitra PKM is a junior high school building located in the Menteng area, Central Jakarta. In recent years the Mitra Area has overcome flooding disasters, the teaching and learning process in the Mitra region has being obstructed. The clean water crisis also occurs in the Mitra area, this is due to the location of the Mitra which is quite connected to office buildings that have a large enough need of clean water. The average rainfall in Indonesia is $2779 \mathrm{~mm}$ per year, in Jakarta around $2500 \mathrm{~mm}$ per year, with a total of 180 rainy days/year. According to average rainfall, is the potentially of water resources and it can be utilized optimally. Sources for water specifically rainwater resources by making infiltration wells. Infiltration wells work to collect surface water and then absorb the soil to become ground water reserves. Converting sufficient (surplus) ground water, will compensate for drought in the dry season in the form of water flow.
\end{abstract}

Keywords: Flood, Water Tight, Infiltration Wells, Base Flow

\begin{abstract}
ABSTRAK
Jakarta merupakan salah satu daerah yang sering mengalami banjir. Jakarta makin rentan banjir karena terkait dengan terbatasnya kawasan resapan air. Pembangunan yang masif dengan kondisi permukaan yang kedap air dan terbatasnya resapan air tanah menyebabkan sekitar $85 \%$ curah hujan yang jatuh di wilayah Jakarta dikonversi menjadi aliran permukaan. Akibat kurangnya resapan di Jakarta, jumlah air hujan yang turun dan mengalir ke laut dan sungai akan bertambah banyak. Saat kapasitas sungai tidak menyanggupi otomatis air sungai meluap dan menyebabkan banjir. Mitra PKM merupakan bangunan sekolah menengah pertama negeri yang terletak di daerah Menteng, Jakarta Pusat. Wilayah Mitra beberapa tahun terakhir mengalami bencana banjir, hal tersebut cukup mengganggu proses belajar mengajar di wilayah Mitra. Krisis air bersih juga terjadi di wilayah Mitra, hal ini diakibatkan lokasi Mitra yang cukup berdekatan dengan bangunan-bangunan perkantoran yang memiliki kebutuhan air bersih yang cukup besar. Curah hujan rata-rata di Indonesia adalah $2779 \mathrm{~mm}$ per tahun, di Jakarta sekitar $2500 \mathrm{~mm}$ per tahun, dengan jumlah air hari hujan 180 hari/tahun. Dengan rata-rata curah hujan yang cukup besar merupakan potensi sumber daya air yang dapat dimanfaatkan secara maksimal. Usaha untuk memanfaatkan sumber daya air khususnya air hujan adalah dengan cara membuat sumur resapan. Sumur resapan berfungsi untuk menampung air permukaan dari hujan dan kemudian meresapkan kedalam tanah untuk menjadi cadangan air tanah. Ketersediaan air tanah yang cukup (surplus), akan mengimbangi kekeringan pada musim kemarau dalam bentuk air aliran base flow.
\end{abstract}

Kata kunci: Banjir, Kedap Air, Sumur Resapan, Base Flow 


\section{PENDAHULUAN}

\subsection{Analisis Situasi}

Hujan merupakan salah satu siklus hidrologi yang dapat membantu pelestarian air tanah (khususnya air tanah dangkal). Ketika musim hujan turun, sebagian besar air akan terbuang langsung ke laut, selain juga menimbulkan daerah-daerah genangan dan banjir. Sebaliknya, ketika musim kemarau, sumber air milik warga banyak yang mengalami kekeringan. Padahal hingga kini, masih banyak masyarakat yang menggunakan air tanah. Secara alami, kekurangan air tanah dapat diatasi, apabila sistem/metode pengelolaannya ditangani secara baik. Salah satu cara yang paling efektif adalah peran serta masyarakat untuk ikut aktif di dalam penerapan langsung melestarikan air tanah karena dari semua pencemaran yang terjadi manusialah yang paling merasakan akibatnya.

Jakarta termasuk salah satu daerah yang sering mengalami banjir. Jakarta sempat beberapa kali terkena bencana banjir yang cukup parah. Kejadian banjir yang terjadi di tahun 2007 menyebabkan kurang lebih 60\% wilayah DKI terendam air dengan kedalaman mencapai lebih dari 5 meter. Selain sistem drainase yang buruk, banjir berawal dari hujan yang lebat selama 2 hari ditambah dengan banyaknya volume air dari 13 sungai yang melintasi Jakarta yang tidak bisa tertampung lagi. Banjir di tahun 2013 yang menyebabkan 20 korban meninggal dunia dan 33.500 orang mengungsi. Diperkirakan banjir tersebut menyebabkan kerugian hingga Rp 20 triliun.

Jakarta makin rentan banjir karena terkait dengan terbatasnya kawasan resapan air. Pembangunan yang masif dengan kondisi permukaan yang kedap air dan terbatasnya resapan air, dan konservasi air tanah telah menyebabkan sekitar $85 \%$ curah hujan yang jatuh di wilayah Jakarta dikonversi menjadi aliran permukaan. Hanya sekitar $15 \%$ yang tertahan di permukaan tanah dan meresap ke dalam tanah. Akibat kurangnya resapan buatan di Jakarta, jumlah air hujan yang turun dan mengalir ke laut dan sungai akan bertambah banyak. Saat kapasitas sungai tidak menyanggupi otomatis air sungai meluap dan menyebabkan banjir. Itulah yang menyebabkan setiap hujan deras sering timbul banjir dan genangan.

Faktor perubahan tata guna lahan dari daerah yang belum dibangun menjadi daerah yang dibangun dapat mempengaruhi aliran air sungai. Dengan adanya perubahan tata guna lahan debit air limpasan akan lebih besar yang akan berpengaruh pada debit aliran sungai dan juga kualitas air sungai itu sendiri (Hendra, 2002) ${ }^{1}$.

Perubahan penggunaan lahan dari daerah pertanian/perkebunan/hutan/rawa menjadi daerah pemukiman akan menyebabkan berkurangnya daerah infiltrasi alami. Sehingga apabila hujan turun pada daerah tersebut maka air hujan akan dengan cepat berubah menjadi aliran permukaan. Air hujan yang telah berubah menjadi aliran permukaan tersebut akan semakin banyak dan segera mengalir ke tempat yang lebih rendah untuk seterusnya masuk kedalam sungai menjadi aliran sungai. Keadaan semacam inilah yang sering kali menimbulkan banjir bahkan oleh hujan yang kecil sekalipun.

Demikian pula halnya dengan Jakarta, sebagai akibat dari perubahan penggunaan lahan telah menyebabkan berkurangnya lahan yang sebelumnya merupakan zone infiltrasi alami. Perubahanperubahan yang menyebabkan zone infiltrasi menjadi berkurang antara lain: a. Lahan yang dipakai untuk bangunan. b. Lahan yang dipakai untuk jalan, c. Lahan yang diaspal/beton. d. Tubuh air (situ, danau alam, dan rawa alam) yang ditimbun.

Air merupakan sumber daya alam yang dikuasai oleh negara dan dimanfaatkan untuk kesejahteraan rakyat. Sumber daya air sangat dibutuhkan oleh setiap mahluk hidup demi kelangsungan hidupnya. Akan tetapi krisis air sedang melanda di berbagai benua di dunia, bahkan benua Asia yang mempunyai curah hujan yang cukup tinggi masih saja dilanda wabah kekeringan 
di beberapa negara, termasuk Indonesia. Oleh sebab itu pemanfaatan sumber daya air harus dilakukan secara bijak.

Menurut data Badan Geologi pada tahun 2009, eksplorasi air tanah telah mencapai angka 40\%. Angka ini menunjukkan tingkat eksplorasi air tanah berada dia atas ambang batas ekplorasi air tanah yang direkomendasikan yaitu di angka 20\%. Hal ini diperparah dengan kurangnya daerah resapan air di Jakarta dan sekitarnya. Eksploitasi air tanah yang berlebihan akan menyebabkan penurunan muka tanah (Land-Subsidence), Intrusi Air Laut, dan lain sebagainya (Indriatmoko, $2003)^{2}$.

Curah hujan rata-rata di Indonesia adalah $2779 \mathrm{~mm}$ per tahun, di Jakarta sekitar $2500 \mathrm{~mm}$ per tahun, dengan jumlah air hari hujan 180 hari/tahun. Jika dihitung maka intensitas hujan ratarata adalah $0,01388 \mathrm{~mm} /$ hari-hujan. Dengan rata-rata curah hujan yang cukup besar maka diperlukan adanya usaha-usaha untuk memanfaatkan sumber daya air khususnya air hujan salah dengan membuat metode-metode peresapan air ke dalam tanah. Beberapa diantaranya adalah metode Sumur Resapan, Lubang Biopori, Kolam Konservasi, Kolam Retensi dan masih banyak lagi.

Sumur resapan adalah suatu rekayasa teknik konservasi air tanah berupa bangunan yang dibuat menyerupai bentuk sumur gali dengan kedalaman tertentu yang berfungsi sebagai tempat untuk memasukkan air hujan yang jatuh di atas atap rumah atau wilayah kedap air untuk diresapkan ke dalam tanah. Manfaat yang didapat dari pembuatan sumur resapan yaitu: a. Menambah jumlah air yang masuk ke dalam tanah, sehingga dapat membantu menanggulangi kekurangan air bersih. b. Mengurangi limpasan permukaan sehingga dapat mencegah banjir. c. Melestarikan dan memperbaiki kualitas lingkungan. d. Membudayakan kesadaran lingkungan. e. Mencegah terjadinya erosi tanah (Bebas banjir2025.wordpress, 2014).

Keuntungan yang dapat diperoleh jika melakukan konservasi dengan menggunakan sumur resapan adalah: a. Mencegah intrusi air laut terutama didataran pantai. b. Mereduksi dimensi jaringan drainase, dapat sampai nol jika diperlukan. c. Menurunkan konsentrasi pencemaran air tanah. d. Mempertahankan tinggi muka air tanah. e. Mencegah penurunan kawasan atau land subsiden. f. Melestarikan teknologi tradisionil sebagai budaya bangsa. g. Meningkatkan peran serta masyarakat dalam era pembangunan. h. Membudayakan pola pikir pelestarian lingkungan (Enviro.bppt.go.id, 2018) .

Beberapa peraturan yang terkait dengan pemanfaatan air hujan salah satunya adalah Peraturan Menteri Negara Lingkungan Hidup Nomor 12 Tahun 2009 tentang Pemanfaatan Air Hujan. Di dalam Permen tersebut di Pasal 1 dijelaskan definisi dari pemanfaatan air hujan, yaitu serangkaian kegiatan mengumpulkan, menggunakan, dan/atau meresapkan air hujan ke dalam tanah. Serangkaian kegiatan tersebut dapat berupa pembuatan Sumur Resapan, Kolam Pengumpul Air dan Lubang Resapan Biopori (jdih.menlh.go.id, 2009) .

Peraturan lain yang terkait dengan sumur resapan adalah adanya Peraturan Gubernur DKI Jakarta No. 20 Tahun 2013 tentang Sumur Resapan pasal 3 ayat 1 yaitu Kewajiban pembuatan sumur resapan bagi perorangan dan badan hukum ditujukan kepada: a. setiap pemilik dan bangunan gedung yang menutup permukaan tanah; dan b. setiap pemohon dari pengguna air tanah.

\subsection{Permasalahan Mitra}

Mitra masyarakat yang akan bekerjasama dalam melaksanakan Program Kemitraan masyarakat Jurusan Teknik Sipil ini adalah SMP Negeri 8 yang berlokasi di Kecamatan Menteng, Jakarta Pusat. SMPN 8 merupakan wadah akademik dalam mengelola generasi penerus bangsa 
secara intelektual yang sangat besar potensinya untuk memanfaatkan sumber daya air berupa air hujan sebagai metode penanggulangan banjir dan genangan melalui pembuatan sumur resapan.

Mitra PKM merupakan bangunan sekolah menengah pertama negeri yang terletak di daerah Menteng, Jakarta Pusat merupakan daerah yang terletak di pusat kota, yang dikelilingi oleh kegiatan bisnis berupa perkantoran yang tepatnya berada di daerah Segitiga Emas Kuningan. Pada beberapa tahun terakhir wilayah di sekitar Mitra mengalami bencana banjir yang cukup besar, sehingga hal tersebut mengganggu proses belajar mengajar yang ada di SMP Negeri 8, Menteng, Jakarta Pusat. Selain banjir yang melanda pada musim penghujan, pada musim kemarau juga terjadi krisis air bersih yang melanda wilayah Mitra. Krisis air yang terjadi disebabkan oleh berkurangnya air tanah yang sedikit banyak diakibatkan oleh pemakaian air tanah yang berlebihan oleh bangunan-bangunan perkantoran yang ada di sekitar wilayah Mitra.

Salah satu cara yang paling efektif menangulangi masalah tersebut adalah peran serta civitas akademik SMP Negeri 8 untuk ikut aktif di dalam penerapan langsung melestarikan air tanah karena dari semua pencemaran yang terjadi manusialah yang paling merasakan akibatnya. Untuk itu, perlu diadakan sosialisasi mengenai sumur resapan penampung air hujan dalam mengatasi masalah air tanah tersebut. Sumur resapan merupakan suatu upaya untuk meresapkan air hujan dalam rangka menambah cadangan air tanah. Sumur resapan dapat menambah jumlah air yang masuk kedalam tanah sehingga dapat mencegah intrusi air laut, dapat menambah jumlah air yang masuk kedalam tanah dan mengisi pori-pori tanah hal ini akan mencegah terjadinya penurunan tanah, mencegah banjir dan genangan.

\section{METODE}

\subsection{Tahapan Kegiatan}

Secara garis besar tahapan kegiatan PKM dapat di kelompokkan menjadi tiga tahapan yaitu : tahap persiapan, tahap pelaksanaan kegiatan, tahap evaluasi dan pembuatan laporan hasil. Penjelasan langkah-langkah kegiatan PKM sebagai berikut:

\section{A. Tahap Persiapan}

\section{Studi Literatur}

Pada tahap ini dilakukan pencarian referensi-referensi kegiatan yang berhubungan dengan kegiatan PKM yang akan dilaksanakan.

2. Penentuan Mitra

Pada tahap ini dilakukan pencarian Mitra tempat dilaksanakan kegiatan PKM sesuai dengan rumusan program dan rancangan kegian PKM

B. Tahap Pelaksanaan

Pembuatan Sumur Resapan

Pada Tahap ini adalah pembuatan sumur resapan sesuai dengan gambar rencana pada proposal PKM

C. Tahap Evaluasi dan Pembuatan Laporan

Pada tahap ini merupakan evaluasi terhadap hasil sumur resapan mengacu pada situasi dan kondisi disaat proses kegiatan sosialisasi dan pembangunan sumur resapan dan kendalakendala yang dihadapi dan pembuatan laporan PKM. 


\subsection{Sifat dan Bentuk Kegiatan}

Kegiatan Penanggulangan Banjir/Genangan dan Konservasi Air Tanah Dengan Pembuatan Sumur Resapan ini merupakan lanjutan dari kegiatan PKM Jurusan Teknik Sipil STT PLN periode sebelumnya dimana sebelumnya telah dilakukan sosialisasi pemanfaatan air hujan dengan pembuatan sumur resapan untuk menanggulangi bajir/genangan yang diikuti oleh $20-25$ peserta dan pembuatan satu sumur resapan. Kegiatan PKM kali ini adalah melanjutkan pembuatan sumur resapan sebanyak 2 (dua) buah, dimana Mitra tempat PKM dilaksanakan mereka membutuhkan 6 (enam) buah sumur resapan untuk mencegah terjadinya banjir/genangan di lokasi Mitra tersebut.

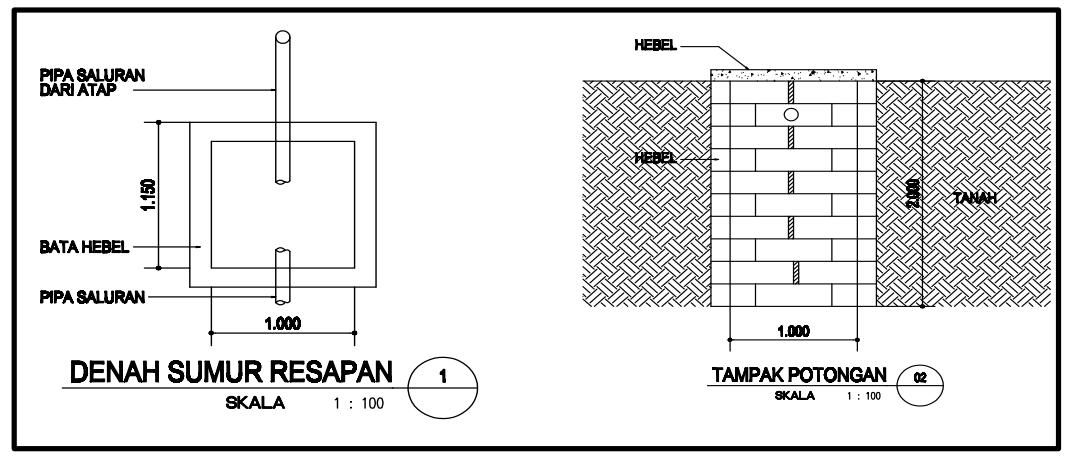

Gambar 1. Rencana Desain Sumur Resapan

Adapun bentuk kegiatan yang akan dilakukan adalah : Sesi pertama atau hari pertama kegiatan adalah penjelasan pembuatan sumur resapan, mendatangkan semua material yang dibutuhkan untuk pembuatan dua sumur resapan di lokasi Mitra, kemudian dilanjutkan dengan survey lokasi tempat dibuatnya sumur resapan. Sesi kedua dilakukan pada hari kedua. Pada sesi kedua ini dilakukan pembuatan Sumur Resapan. Pembuatan Sumur Resapan ini dilakukan oleh seluruh anggota tim dan Mitra. Berikut merupakan desain Sumur Resapan yang dibangun pada wilayah Mitra.

\section{HASIL DAN PEMBAHASAN}

\subsection{Hasil}

Kegiatan sosialisasi pemanfaatan air hujan dengan teknik pembuatan sumur resapan dalam rangka untuk menumbuhkan sikap peduli terhadap lingkungan khususnya terhadap bahaya banjir/genangan dan bahaya kekeringan telah dilaksanakan.

Hasil dari kegiatan sosialisasi pemanfaatan air hujan dengan teknik pembuatan sumur resapan dan pembangunan sumur resapan yang merupakan tujuan dari kegiatan PKM ini, antara lain adalah:

1. Melalui kegiatan sosialisasi ini tim kegiatan PKM telah membantu dalam menyebarluaskan dan menerapkan hasil dari penelitian dan kajian kepada masyarakat sebagai upaya dalam memberdayakan dan meningkatkan kualitas hidup masyarakat dengan teknologi sumur resapan dalam menangani banjir dan konservasi air tanah.

2. Melalui kegiatan PKM ini merupakan bentuk kerjasama dan kemitraan dengan masyarakat sebagai perwujudan dari pengembangan kompetensi sosial di kalangan para dosen.

3. Melalui kegiatan PKM ini diharapkan dapat menumbuhkan kesadaran akan memenuhi kewajiban pembangunan Sumur Resapan yang sesuai dengan Peraturan Gubernur DKI Jakarta No. 20 tahun 2013 tentang Sumur Resapan. 
4. Sumur Resapan yang telah dibangun untuk dapat dimanfaatkan sesuai dengan penggunaannya di SMPN 8, Menteng Jakarta Pusat, tepatnya untuk menampung air hujan yang berasal dari atap masjid di SMPN 8 sebanyak 1 buah sumur.

5. Seluruh civitas SMPN 8 memahami konsep sumber daya air tak terbarukan yang merupakan konsep teknologi pengisian air tanah (water recharge) dengan metode sumur resapan, sebagai siasat untuk pemenuhan kebutuhan air tanah di masa yang akan datang.

6. Melalui kegiatan PKM ini diharapkan dapat mengembangkan kesadaran masyarakat mengenai bagaimana cara menanggulangi banjir pada skala kecil terlebih dahulu yaitu pada tingkat rumah tangga sampai ke tingkat yang lebih luas lagi, sekolah, bangunanbangunan perkantoran, dan lain-lain. Juga meningkatkan kesadaran mengenai aktivitas menjaga kebersihan dengan tidak membuang sampah sembarangan apalagi di sungaisungai yang dapat menimbulkan permasalahan banjir.

\subsection{Pembahasan}

Sesuai dengan rencana target luaran dengan pelaksanaan kegiatan sosialisasi pemanfaatan air hujan dengan teknik pembuatan sumur resapan diharapkan dapat membantu dalam meningkatkan pengetahuan dan kesadaran dalam penerapan IPTEK di kalangan masyarakat umum. Diawali dengan Progra, Kemitranan Masyarakat Tahap Pertama yang telah dilaksanakan pada Kamis, 14 Februari 2019 pada pukul 13.00 WIB sampai dengan selesai, semester Ganjil 2018/ 2019 lalu. Sedangkan pembangunan Sumur Resapan Tahap Pertama dilaksanakan 4 hari yaitu pada hari Jum'at, 14 - 17 Februari 2019. Sosialisasi dihadiri oleh tim PKM yang terdiri dari dosen Jurusan Teknik Sipil STT PLN Jakarta serta diikuti oleh 25 peserta yang terdiri dari Kepala Sekolah, Bapak/Ibu Guru peserta PokJa, siswa-siswi pelajar di SMPN 8, Menteng Jakarta Pusat.
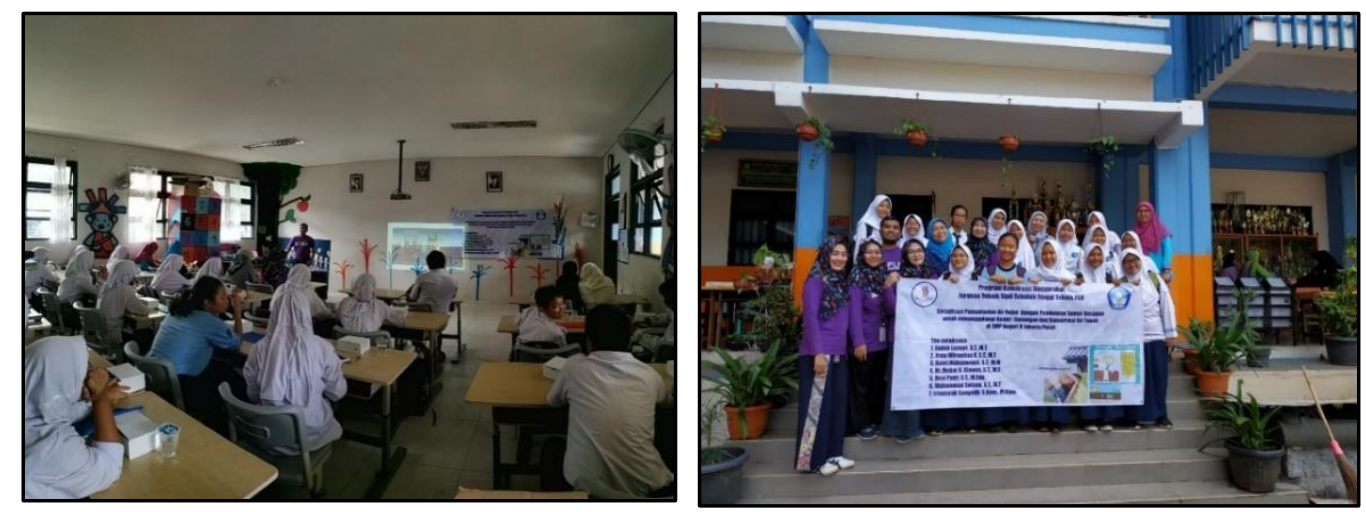

Gambar 2. Sosialisasi Pemfaatan air hujan dengan Teknik pembuatan sumur resapan
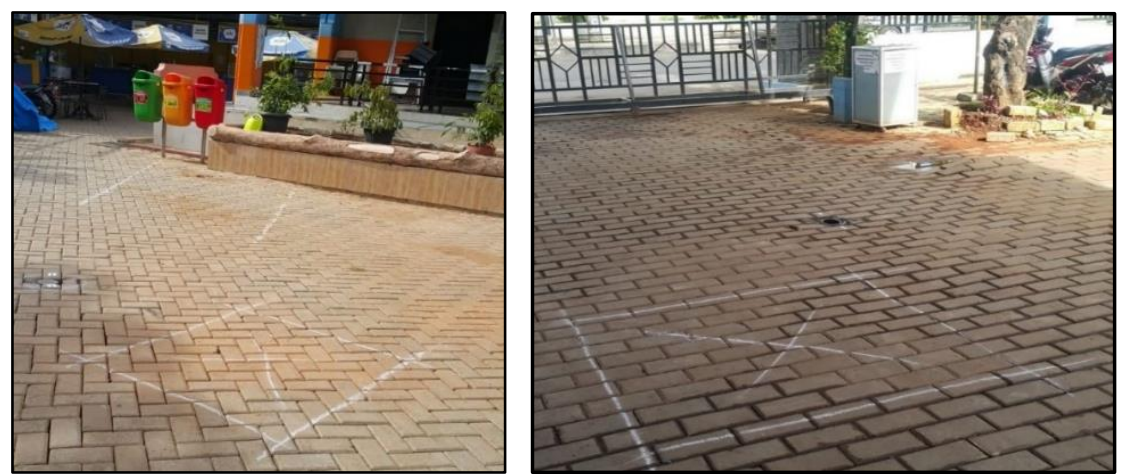

Gambar 3. Pemilihan lokasi target sumur resapan, yaitu pada lokasi yang rawan genangan. 


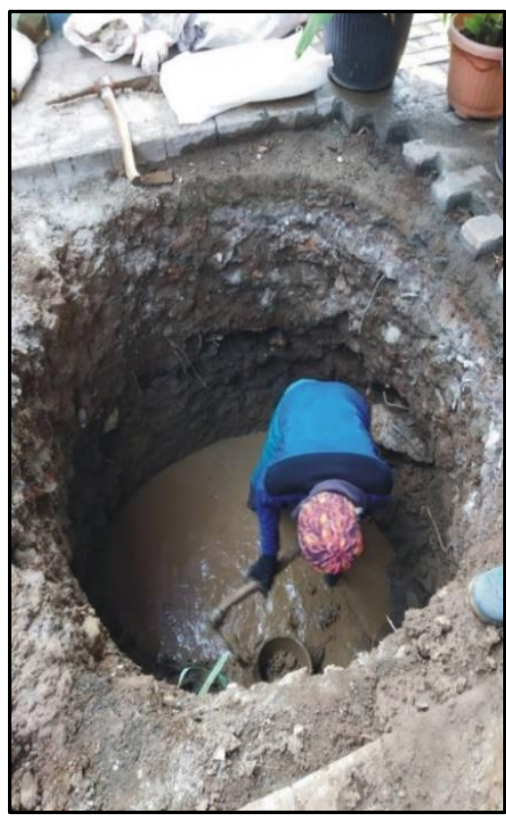

A

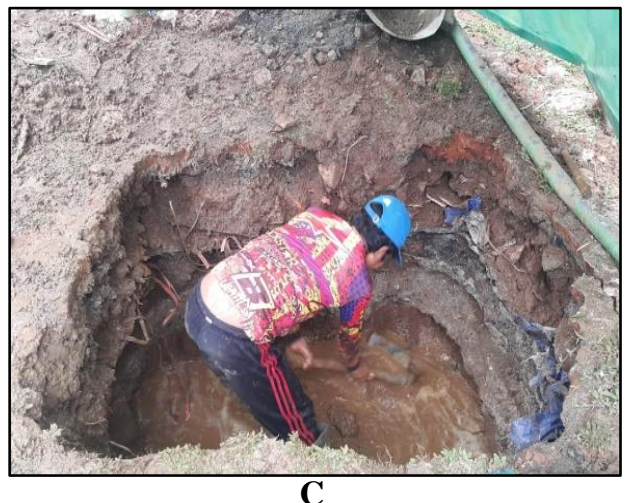

C

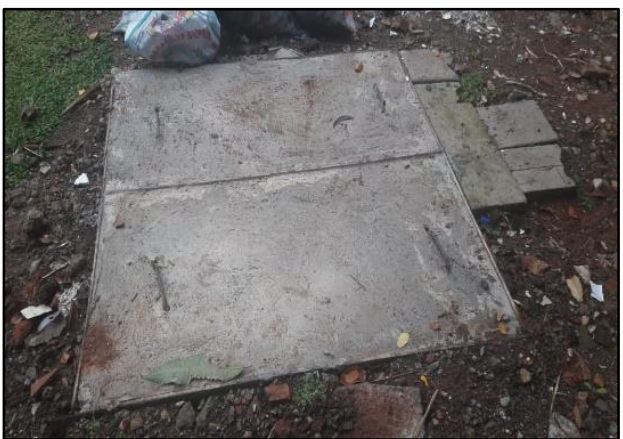

$\mathbf{E}$

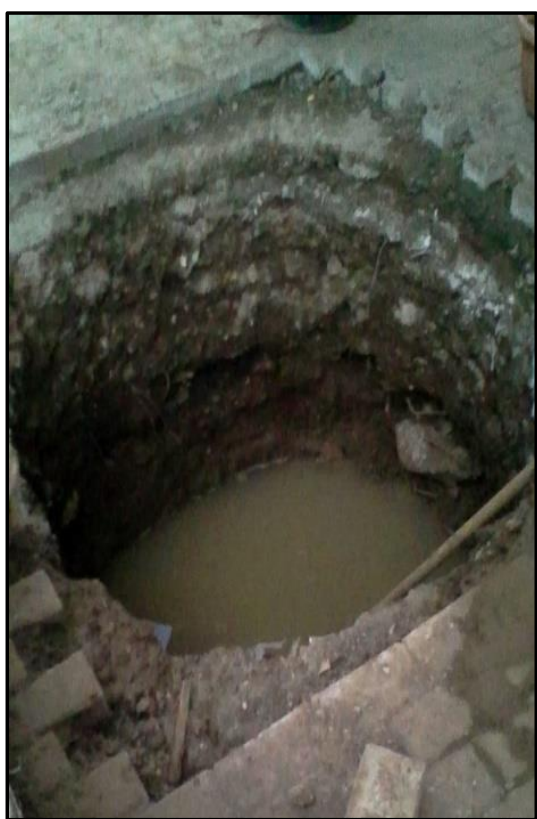

B

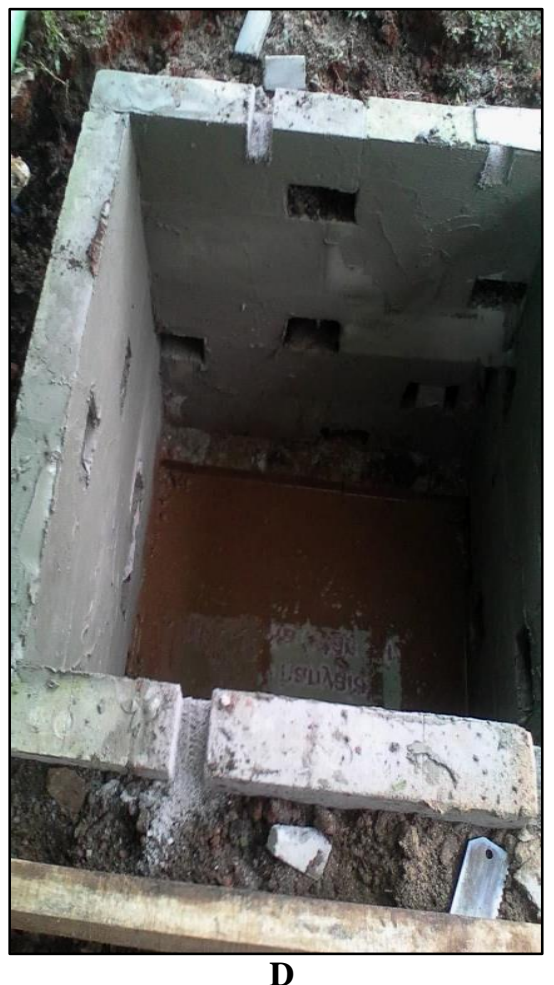

D

Gambar 4. (A) Peggalian sumur resapan. (B). Lubang sumur resapan yang kontak dengan muka air tanah, (C) Penggalian sumur resapan lokasi kedua, (D). Pemasangan dinding hebel. (E). Pemasangan penutup sumur resapan

Dilanjutkan dengan Program Kemitraan Tahap Kedua, yaitu optimalisasi pembuatan sumur resapan pada Jumat, tanggal 19 Juli 2019 sebanyak 2 (dua) buah. Kegiatan PKM ini tentunya belum mampu menyelesaikan permasalahan Mitra dalam mengatasi banjir dan krisis air bersih di wilayah Mitra, namun setidaknya melalui kegiatan PKM ini Mitra lebih memahami bagaimana cara mengurangi jumlah air permukaan yang berasal dari air hujan. Dengan mengurangi jumlah air 
permukaan maka genangan bahkan banjir dapat dihindari. Kegiatan ini agar diharapkan Mitra dapat memahami cara kerja dari Sumur Resapan sebagai salah satu cara pengelolaan Sumber Daya Air khususnya air hujan. Dengan menggunakan metode memasukkan air hujan ke dalam tanah (water recharge) Mitra juga memahami bahwa dengan pembangunan Sumur Resapan merupakan salah satu cara dalam mengatasi kekurangan air tanah dan kekeringan di masa yang akan dating.

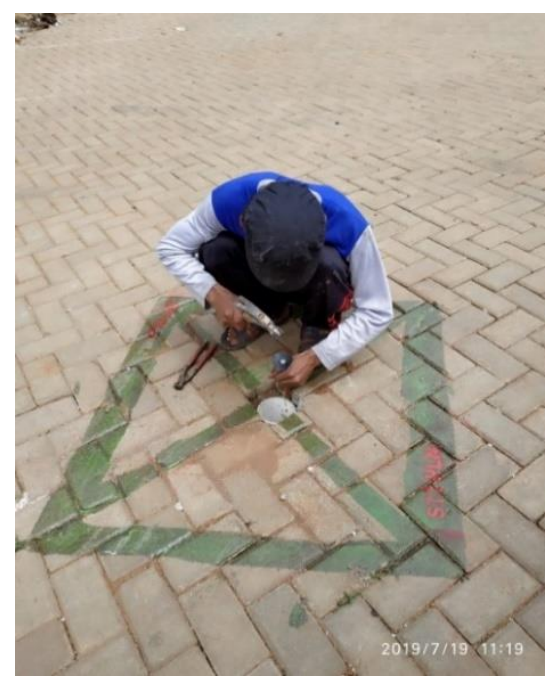

A

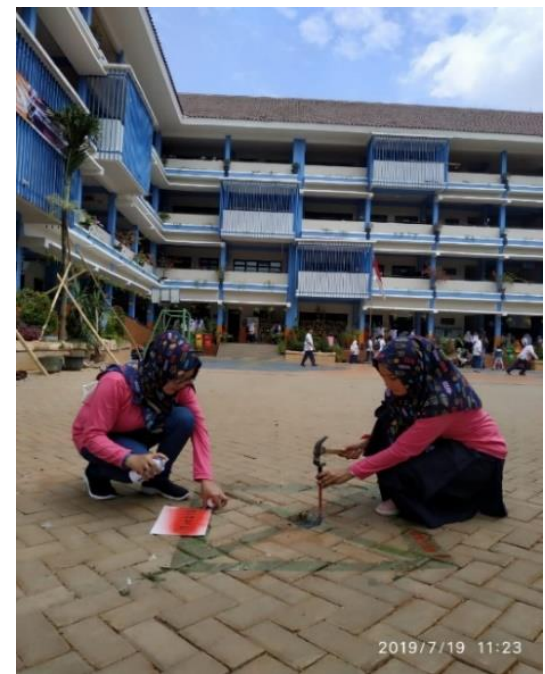

C

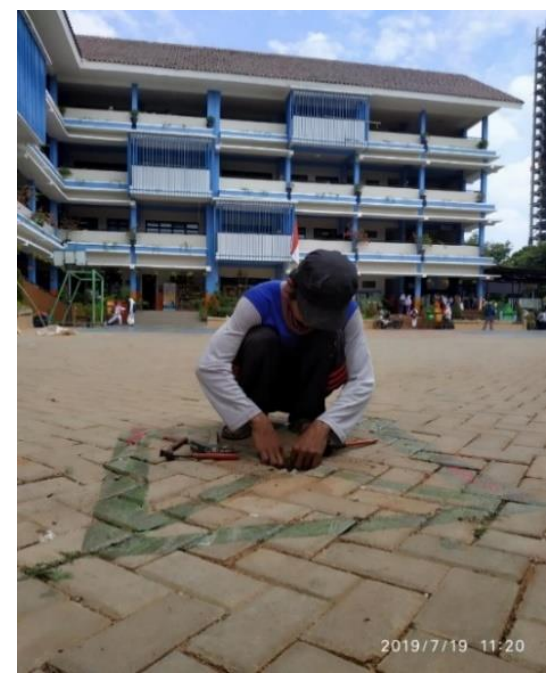

B

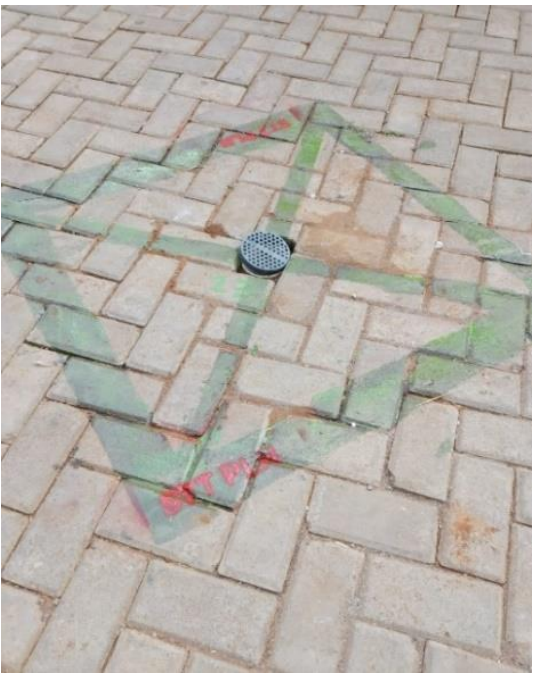

D

Gambar 5. (A \& B) Pembuatan lubang saringan sumur resapan. (C) Finishing pemasangan tutup saringan sumur resapan dan pembuatan label STT-PLN (D). Sumur resapan yang sudah jadi dan siap untuk digunakan.

\section{KESIMPULAN}

Kesimpulan yang dapat diambil dari kegiatan Program Kemitraan Masyarakat dengan tema Penanggulangan Banjir/Genangan dan Konservasi Air Tanah Dengan Pembuatan Sumur Resapan, adalah: 
1. Melalui kegiatan PKM ini diharapkan dapat menumbuhkan kesadaran akan memenuhi kewajiban pembangunan Sumur Resapan yang sesuai dengan Peraturan Gubernur DKI Jakarta No. 20 tahun 2013 tentang Sumur Resapan.

2. Melalui kegiatan PKM dapat memberikan kesadaran kepada masyarakat untuk pemanfaatan air hujan sebagai sumber daya air yang melimpah dengan pembuatan Sumur Resapan. Kegiatan dimaksudkan agar dapat menyadarkan masyarakat mengenai arti pentingnya melestarikan air tanah dengan cara memasukkan air ke dalam tanah (water recharge) untuk menghadapi musim kemarau.

3. Keberhasilan kegiatan PKM ini harus didukung oleh seluruh elemen masyarakat yaitu tim pelaksana PKM, institusi tim pelaksana PKM dan pihak Mitra guna meningkatkan rasa tanggung jawab terhadap lingkungan hidup sekitarnya dalam mengatasi bencana banjir dan kekeringan.

4. Berdasarkan evaluasi yang dilakukan terhadap kegiatan PKM ini menunjukkan perlunya diadakan kegiatan serupa dengan Mitra yang berbeda agar penyebarluasan informasi IPTEK lebih merata ke semua pihak dan elemen masyarakat sehingga mendapatkan hasil yang maksimal.

\section{SARAN}

Berdasarkan kendala dan uraian kegiatan di atas, saran-saran yang dapat diberikan antara lain adalah:

1. Agar mendapatkan hasil yang maksimal dalam pemanfaatan air hujan dalam menanggulangi banjir/genangan dan konservasi air tanah, hendaknya Mitra dapat melakukan pengembangan dengan membuat metode-metode lain selain sumur resapan di wilayah Mitra.

2. Untuk mengatasi cukup mahalnya material dan biaya pembuatan sumur resapan, maka perlu adanya penggantian material yang lebih terjangkau contohnya dengan menggunakan batu bata dan batako. Sehingga masyarakat umum dapat membangun sumur resapan pada lahan hunian masing-masing sesuai dengan persyaratan yang ada.

3. Pemilihan Mitra selanjutnya diharapkan agar dapat mempertimbangkan kebutuhan Mitra, yaitu Mitra yang lokasinya berada pada daerah rawan banjir atau bahkan daerah bantaran sungai.

\section{UCAPAN TERIMA KASIH}

Ucapkan terima kasih atas pendanaan PKM ini oleh Sekolah Tinggi Teknik PLN Tahun Ajaran 2018/2019 dan juga semua pihak-pihak yang telah membantu terlaksananya kegiatan pengabdian pada masyarakat ini.

\section{DAFTAR PUSTAKA}

[1] Hendra T.W., Ruslin. A., Agus. S (2002). Manfaat Sumur Resapan Dalam Penanggulangan Banjir di Wilayah Kelurahan Penanggulangan Banjir Di Wilayah Kelurahan Penanggungan Bagian Selatan Kota Malang. Jurnal Teknik Sipil Fakultas Teknik Universitas BrawijayaKodoatie, Robert J. 2013. Rekayasa dan Manajemen Banjir Kota. Yogyakarta: Penerbit Andi.

[2] Indriatmoko, R.H., Herlambang, Ari., (2003). Penanggulangan Banjir Dengan Jaring Pengaman Sosial Sumur Resapan di Jakarta Dan Sekitarnya. Jurnal Teknologi Lingkungan. $4(2), 36-42$. 
[3] Sumur Resapan termuat di https://bebasbanjir2025.wordpress.com/teknologi-pengendalianbanjir/sumur-resapan/ diakses 16 Maret 2018

[4] Konservasi Air Tanah Dengan Sumur Resapan termuat http://www.enviro.bppt.go.id/ diakses 17 September 2018

[5] Peraturan Menteri Negara Lingkungan Hidup Nomor 12 Tahun 2009 tentang Pemanfaatan Air Hujan termuat di http://jdih.menlh.go.id/pdf/ind/IND-PUU-7-2009Permen\%20No.12\%20Tahun\%202009-Pemanfaatan\%20Air\%20Hujan_Combine.pdf diakses 06 Maret 2018

[6] Maryono, Agus. 2014. Menangani Banjir, Kekeringan, dan Lingkungan. Yogyakarta: Penerbit Gadjah Mada University Press. 